Primljeno: 24. 9. 2020.

Prihvaćeno za štampu: 23. 11. 2020.

\author{
Dr. sc.Vildana Aziraj-Smajić, docent \\ Kantonalna bolnica "Dr. Irfan Ljubijankić", \\ Odjel - Neuropsihijatrija, Bihać, \\ E-mail:v.aziraj@gmail.com
}

Mr. sc. Mirela Mujagić

Kantonalni sud u Bihaću

E-mail:poprzenovicm@gmail.com

\title{
PSIHOLOŠKI EFEKTI KARANTENE U VRIJEME PANDEMIJE COVID-19
}

\section{Sažetak}

Mnoge države, uključujući i Bosnu i Hercegovinu, su stavile cijele gradove u karantenu $i$ uveli policijski čas vjerujuci da je to najefikasniji način kontroliranja širenja COVID-19. Iako karantena, kao metoda izbora u prevenciji sirenja zaraznib bolesti, može biti vrlo efikasna, istovremeno za pojedinca mo ̌̌e predstavljati iznimno neugodno iskustvo. Odvajanje od bliskih osoba, neizvjesnost u odnosu na zdravstveno stanje, gubitak slobode kretanja, ograničavanje u svakodnevnim navikama i aktivnostima, može povećati riqik od raqvoja anksioznosti, depresije, posttraumatskih stresnih simptoma, kao i druge psihopatološke simptomatike. U funkeciji iabjegavanja nelagode koju sa sobom nosi karantena, dešava se da pojedinci pribjegavaju prikrivanju simptoma COVID-19 sto može rezultirati nepovoljnim efektima za javno zdravstvo. Imajuci u vidu navedeno ne iznenaduje činjenica da je u posljednje vrijeme fokus istraživanja usmjeren upravo na ispitivanje njenog utjecaja na mentalno zdravlje pojedinca. Pojedini autori izražavaju stav da ce pandemija COVID-19 requltirati pandemijom psibičkih poreméaja. Cilj ovog preglednog rada se ogleda u sumiranju dosadašnjih naúnih spoznaja o psibološkim efektima karantene kao i njihova integracija u aktualni zdravstveno-socijalni kontekst u Bosni i Hercegovini. Namjera nije predstaviti karantenu kao nepoželinu preventivnu mjeru, nego povećati svijest o značaju psiboloskee njege i brige za mentalno zdravlje pojedinca kojem je ovakva mjera odredena.

Ključne riječi: karantena, COVID-19, psibološki efekti 


\section{Uvod}

Eksponencijalno i nekontrolisano širenje infekcije virusom COVID-19 zabilježeno je u mnogim zemljama širom svijeta u decembru 2019. godine. Imajući u vidu da se radi o potpuno novom virusu za kojeg se vežu mnoge nepoznanice, profesionalci su se našli u nezavidnoj poziciji pri odabiru efikasnih mjera kontrole širenja ove prenosive zarazne bolesti. Jedna od mjera koju su uvele mnoge države je mjera obavezne karantene (Brooks i sar., 2020, Hawryluck i sar., 2004).

U procesu odabira adekvatnih mjera, dužna pažnja se posvetila razmatranju specifičnosti vezanih za karantenu i načinima promocije obaveznog poštivanja mjera preporučenih za kontrolu širenja virusa. Dok su krizni štabovi i profesionalci bili fokusirani na sprečavanje širenja virusa i očuvanje fizičkog zdravlja stanovništva, zanemareni su efekti ove pandemije i preporučenih mjera na njihovo mentalno zdravlje. Međutim, cijeneći brojne pozitivne efekte uvođenja ove mjere u sprečavanju širenja virusa COVID-19, ne smijemo zanemariti i pojavu njenih potencijalno nepovoljnih efekata po mentalno zdravlje osoba kojima je ovakva mjera propisana.

Iako aktualno ne raspolažemo dostatnim empirijskim podacima o efektima karantene uvedene u vrijeme pandemije virusa COVID-19, na osnovu rezultata ranijih istraživanja, malobrojnih novih istraživanja, onih koji su objavili preliminarne rezultate te profesionalnih znanja baziranih na iskustvu pružanja psihosocijalne podrške u vrijeme navedene pandemije, dolazi se do zaključaka da ovakva mjera prevencije bolesti može ostaviti značajne posljedice po mentalno zdravlje pojedinca.

Cilj ovog preglednog rada jeste prezentirati dosadašnje naučne spoznaje o karanteni kao metodi izbora u funkciji prevencije širenja zaraznih bolesti te ih integrirati u aktualni zdravstveno-socijalni kontekst u Bosni i Hercegovini.

\section{Karantena kao preventivna mjera širenja zaraznih bolesti i njeni psihološki efekti}

Karantena (samoizolacija, kućna karantena - eng. home qarantine) podrazumijeva preventivnu mjeru koja odvaja i ograničava kretanje osoba koje su usljed potencijalne izloženosti infekciji pod povišenim 
rizikom od razvoja bolesti te samim tim njihovo prisustvo u socijalnim kontaktima može ugroziti zdravlje drugih. Termin izolacija (hospitalna ili kućna izolacija) koji se ponekad koristi kao sinonim, za razliku od karantene podrazumijeva odvajanje i ograničenje osoba kojima je već dijagnosticirana zarazna bolest (CDC, 2020). Karantena se decenijama periodično koristila za suzbijanje i kontrolu širenja infektivnih bolesti kao što su SARS, kuga i kolera, ali njena uspješnost u funkciji preventivne strategije za očuvanje tjelesnog zdravlja je, na neki način, zasjenjena nepovoljnim posljedicama na mentalno zdravlje pojedinca. Imajući u vidu navedene nepovoljne posljedice koje se manifestiraju u vidu generaliziranog straha, nedostatka razumijevanja, osjećaja prijetnje, diskriminacije te narušenog socio-ekonomskog statusa, neki autori čak navode da se karantena ne bi trebala smatrati primarnom javnozdravstvenom strategijom za prevenciju širenja zaraznih bolesti (Barbera i sar., 2003; Mandavilli, 2003; Twu i sar., 2003).

\section{Stresori povezani s karantenom}

Boravak u karanteni, koja ograničava slobodu kretanja i kontakt sa socijalnim miljeom, za pojedinca može biti izrazito neugodan. U ovom kontekstu razlikujemo stresore koje pojedinac može percipirati $u$ toku karantene i nakon karantene. Jedan od značajnih stresora identificiran u istraživanjima $u$ vrijeme epidemije SARS-a i Ebole, kod pojedinaca $u$ toku boravka u karanteni jeste strah od infekcije kao i pojave bilo kojeg tjelesnog simptoma koji bi mogao biti povezan s potencijalnom infekcijom i strahom od razbolijevanja (Cava, Fay, Beanlands, McCay i Wignall, 2005; Desclaux, Badji, Ndione i Sow, 2017).

Rezultati nekih studija su ukazali na povezanost između dužine trajanja karantene i prevalencije PTSP simptomatike. Naime, osobe koje su bile u karanteni duže od deset dana pokazivale su značajno teže posttraumatske simptome nego oni čija je karantena trajala kraće (Hawryluck i sar., 2004).

Nadalje, kao značajni stresori povezani s karantenom evidentirani su stigmatiziranost potencijalno zaražene i/ili zaražene osobe, osjećaj dosade i gubitak ranije uobičajene rutine u svakodnevnom životu, reducirani socijalni i fizički kontakt s drugima, osjećaj izoliranosti od ostatka svijeta, finansijske teškoće (Bai i sar., 2004; Hawryluck i sar., 2004; Lee, Chan, Chau, Kwok i Kleinman, 2005; Reynolds i sar. 2008). 


\section{Pregled dosadašnjih istraživanja o utjecaju karantene na mentalno zdravlje}

Pregledom dostupne literature primjećuje se da sve veći broj istraživanja karantenu dovodi $\mathrm{u}$ vezu $\mathrm{s}$ nepovoljnim efektima na mentalno zdravlje stanovništva (Bai i sar., 2004; Liu i sar., 2012; Sprang i Silman, 2013; Taylor i sar., 2008; We i sar., 2009). Tako u istraživanju provedenom na 129 osoba iz Toronta (Kanada), kojima su bile izrečene mjere karantene utvrđena je visoka prevalencija psihološkog distresa. Simptomi posttraumatskog stresnog poremećaja identificirani su kod 28,9\% učesnika, dok su simptomi depresije bili prisutni kod njih 31,2\% (Hawryluck i sar., 2004).

Lee i saradnici (2005) su proveli istraživanje u Hong Kongu koje je obuhvatilo 903 osobe koje su bile u karanteni zbog izloženosti potencijalno SARS pozitivnim osobama. Učesnici ovog istraživanja su najčešće izvještavali o sniženom raspoloženju (73\%), iritabilnosti (57\%) i nesanicama (34,2\%). Njihovu pojavu su pripisivali izloženošću SARS-u (u 79,1\% slučajeva), zatim nepoznatim načinima prenošenja $(73,2 \%)$, stigmatizaciji $(65,1 \%)$, strahu od posljedica liječenja $(56,6 \%$, naglom padu vrijednosti nekretnina $(52,4 \%)$ te striktnim pravilima pridržavanja karantene za SARS pacijente $(51,3 \%)$.

Reynolds i saradnici (2008) su proveli istraživanje na uzorku od 1912 osoba koje su bile u karanteni zbog bliskog kontakta s osobama koje su potencijalno inficirane SARS virusom koristeći Skalu utjecaja događaja (eng. Impact of Events Scale - Revised - IES-R) kako bi procijenili simptome posttraumatskog stresnog poremećaja. Od osjećaja povezanih s karantenom u ovom istraživanju ističu se osjećaj dosade $(62,2 \%)$, osjećaj izolacije $(60,6 \%)$, frustracija $(58,5)$, zabrinutost (40,2\%), usamljenost (38,5\%), bespomoćnost $(31,7 \%)$, ljutnja $(28,8 \%)$, strah $(20 \%)$, nervoza (18\%), tuga (18\%) te osjećaj krivnje (10\%). Neki od učesnika su izvijestili o izraženom strahu da će se zaraziti i strahu da će zaraziti druge. U skladu s tim identificirani su i psihološki efekti karantene na ponašajnom planu i to u vidu izbjegavanja osoba koje kišu ili šmrcaju (54\%), izbjegavanja zatvorenih prostora gdje se okuplja mnogo ljudi (26\%), i izbjegavanja svih javnih prostora sedmicama nakon perioda karantene $(21 \%)$. 
Rezultati kvalitativnih istraživanja pokazuju psihološke efekte karantene kao što su zbunjenost, ljutnja, strah, žalovanje, osjećaj emocionalne otupljenosti te probleme sa spavanjem. Cava i saradnici (2005) su u studiji koja je obuhvatila slučajni uzorak od 21 osobe koje su potencijalno bile u kontaktu sa SARS pozitivnim osobama, identificirali prisustvo osjećaja nesigurnosti, izbjegavanja i problema u suočavanju s teškoćama. Pan, Chang i Yu (2005) su proveli studiju koja je obuhvatila 12 univerzitetskih studenata koji su bili u kućnoj karanteni uslijed izloženosti SARS-u. Bespomoćnost, strah, osjećaj užasa, depresivno raspoloženje, stigmatizacija, alienacija, diskriminacija, odbacivanje od strane zajednice, osjećaj napetosti i preplavljujuće tuge pri izloženosti informacijama o SARS-u te samim tim i izbjegavanja bilo kakvih vezanih informacija i vijesti su se pokazali kao dominantne tegobe. Navedena izbjegavajuća ponašanja su ih dalje ometala u svakodnevnom funkcionisanju, odnosima sa ljudima, produktivnosti na poslu i planiranju budućnosti.

DiGovanni, Conley, Chiu i Zaborski (2004) su proveli komprehenzivnu kvalitativnu studiju koja se sastojala iz nekoliko dijelova. Proveden je nestrukturirani intervju sa 35 stanovnika koji su bili u karanteni, zatim telefonska anketa sa 1509 učesnika iz opće populacije, 6 fokus grupa s pojedincima koji su na određen način bili pogođeni karantenom (zdravstveni radnici, porodice zdravstvenih radnika, opća populacija, srednjoškolci) te strukturirani intervju sa 195 zdravstvenih radnika koji su bili u karanteni. Kao jedan od osnovnih problema koji su ovi učesnici identificirali je psihološki distres koji atribuiraju socijalnoj udaljenosti i stigmatizaciji. Također ističu osjećaj straha, izolacije, usamljenosti, depresije, insomnije i anksioznosti. Posebno ističu osjećaj dosade kao jedan od osnovnih razloga zbog kojih su razmišljali o izlasku iz karantene.

Identificirani su također i psihološki efekti karantene na ponašajnom planu i to u vidu izbjegavanja osoba koje kišu ili šmrcaju (54\%), izbjegavanja zatvorenih prostora gdje se okuplja mnogo ljudi (26\%), i izbjegavanja svih javnih prostora sedmicama nakon perioda karantene (21\%) (Reynolds i sar., 2008). U vezi s tim, pokazane su i dugotrajnije promjene u ponašanju nakon perioda karantene, u vidu učestalog pranja ruku i izbjegavanja gužvi, dok su neki mjesecima odgađali povratak u 
svoju raniju rutinu, tj. uobičajeno funkcioniranje u svakodnevnom životu (Cava i sar., 2005).

Značajno je spomenuti da rezultati dosadašnjih istraživanja u ovom području nisu konzistentni u pogledu prediktora određenih psiholoških odgovora na karantenu. Tako su Taylor i saradnici (2008) proveli istraživanje na uzorku od 2760 osoba koje su bile u karanteni zbog epidemije EL gripe kod kopitara (eng. Equine influenza outbreak). Pored toga što je generalno identificiran viši nivo psihološkog distresa kod osoba koje su bile u karanteni (34\%) u odnosu na opštu populaciju $(12 \%)$, rezultati su, također, pokazali da su mlađa starosna dob, niži nivo formalnog obrazovanja, ženski spol, i manji broj djece povezani s negativnim psihološkim uticajem. Suprotno navedenom, Hawryluck i saradnici (2004) su u istraživanju koje je obuhvatilo 129 osoba nakon što su napustile karantenu, utvrdili da demografski faktori kao što su bračni status, starosna dob, nivo obrazovanja i broj djece nisu povezani s efektima karantene na mentalno zdravlje. Pokazano je da postoji povezanost između veličina ukupnih primanja $u$ domaćinstvu $\mathrm{s}$ depresivnom i PTSP simptomatikom, što su primanja niža simptomi psihološkog distresa su veći.

Istraživanje koje su proveli Madani i saradnici (2020) bavilo se evaluacijom psihološkog utjecaja totalne i parcijalne karantene koja se koristila kao mjera suzbijanja širenja COVID-19 u Alžiru. Na uzorku od 678 učesnika koji su odgovorili na online upitnik pokazano je da se njih 50,3\% nalazilo u anksioznom stanju u prve tri sedmice karantene. O doživljavanju stresa izvijestilo je 48,2\% učesnika, dok se njih 46,6\% žalilo na loše raspoloženje, a njih 47,4\% navelo da konstantno razmišlja o epidemiji i načinu kako da se zaštite. Nadalje, 87,9 \% učesnika je izvijestilo da im je jako teško pratiti sva uputstva kriznog štaba. Značajne promjene su uočene i u svakodnevnim životnim navikama, kao što su vrijeme odlaska u krevet i vrijeme buđenja, količina vremena provedena na internetu kao i vrijeme odvojeno za dnevne rutine.

Efekte COVID-19 karantene na mentalno zdravlje istraživali su također Fawaz i Samaha (2020) kod opće populacije Libanona. Cilj ove studije je bio evaluacija prevalencije posttraumatske stresne simptomatike kao reakcije na COVID-19 karantenu na uzorku od 950 stanovnika Libanona. Rezultati su pokazali da je nakon dvije sedmice karantene 
došlo do porasta PTSP simptomatike, dok je u četiri sedmice karantene došlo do intenziviranja ove simptomatike.

Penga i saradnici (2020) su proveli istraživanje na uzorku od 2237 osoba kojima je bila izrečena mjera karantene zbog potencijalne izloženosti COVID-19. Simptomi depresije su utvrđeni kod 6,21\% učesnika, a među njima su najčešće bile osobe mlađe starosne dobi, nižeg obrazovnog statusa te su postizali više skorove na skalama anksioznosti, depresivnosti, indeksu kvalitete spavanja, kao i skali utjecaja događaja koja se odnosi na prisustvo posttraumatskih stresnih simptoma. Za razliku od osoba koje nisu imale depresivne simptome, ove osobe su pokazivale izbjegavajuća ponašanja, imale su intruzivne misli i simptome pretjerane pobuđenosti organizma.

Casagrande i saradnici (2020) su ispitivali utjecaj karantene na kvalitetu sna, simptomatiku generaliziranog anksioznog poremećaja i psihološkog distresa i to na uzorku od 2291 stanovnika Italije u vrijeme izbijanja pandemije COVID-19. Rezultati ovog online istraživanja su pokazali da je kod 57,1\% učesnika kvaliteta sna bila narušena, kod $32,1 \%$ učesnika bila visoka anksioznost, kod 41,8\% visok psihološki distres dok je kod njih 7,6\% evidentirana PTSP simptomatika povezana s COVID-19.

Cai i sar. (2020) su proveli istraživanje koje je imalo za cilj identificirati prediktore koji su povezani sa simptomima psihološkog distresa kod 126 osoba koje su preživjele COVID-19 infekciju i u vrijeme istraživanja su se nalazili u kućnoj karanteni. Ključni rezultati ove studije pokazuju visoku prevalenciju psiholoških tegoba kod velikog broja preživjelih u ranoj fazi rekonvalescencije, gdje značajan broj zadovoljava dijagnostičke kriterije za kliničku dijagnozu stresne reakcije (31\%), anksioznosti $(22,2 \%)$ i depresivnosti $(38,1 \%)$. Uočena je, također, pozitivna veza između navedenih simptoma i fizičkih tegoba nakon infekcije te pojave infekcije kod članova uže i šire porodice. Zabrinutost za zdravstvene probleme porodice i osjećaj krivnje zbog činjenice da su učesnici izvor zaraze, rezultirala je narušavanjem općeg raspoloženja što je vodilo povećanju simptoma stresa i depresije. Postzarazna fizička nelagoda je neznatno bila povezana sa simptomima stresa i depresije, ali je bila značajan prediktor anksioznosti. Dostatna socijalna podrška se pokazala značajnim protektivnim faktorom s obzirom na to da su osobe s percipiranom 
socijalnom podrškom rjeđe izvještavale o teškim simptomima stresa i depresije. Zanimljiv je podatak da su žene izvještavale o većem intenzitetu stresa i depresije u poređenju s muškarcima. Radni status se, također, pokazao kao važan prediktor psihološkog distresa, gdje su penzioneri pokazivali znatno rjeđe simptome stresa u odnosu na radno angažirane osobe. U ovom istraživanju nije pokazana značajna povezanost između psihološkog distresa i nivoa obrazovanja učesnika niti medicinske povijesti uključujući i povijest $\mathrm{s}$ psihijatrijskih poremećaja.

Međutim, u ranijim istraživanjima potvrđena je značajna povezanost povijesti psihijatrijske bolesti s doživljajem anksioznosti i ljutnje čak četiri do šest mjeseci nakon karantene (Jeong i sar., 2016). Ovi autori su koristeći skalu za dijagnosticiranje generaliziranog anksioznog poremećaja (Generalised Anxiety Disorder 7-item scale) te inventar za ocjenu ljutnje (State-Trait Anger Expression Inventory) ispitali 1692 osobe koje su bile u kontaktu s osobama koje su pozitivne na MERS (eng. Middle Eastern Respiratory Syndrom - Respiratorni sindrom Srednjeg Istoka). Pokazano je da je u vrijeme karantene 7,6\% učesnika pokazivalo simptome anksioznosti dok je ljutnja bila prisutna kod $16,6 \%$ osoba. Po protoku vremena od četiri do šest mjeseci nakon karantene, simptomi anksioznosti su evidentirani kod 3\% učesnika dok je osjećaj ljutnje bio prisutan kod 6,4\% osoba. Kao faktori rizika za razvoj anksiozne simptomatike i osjećaja ljutnje identificirano je: prisustvo simptoma infekcije, neadekvatna snabdjevenost osnovnim životnim zalihama (hrana, odjeća, smještaj), aktivnosti na društvenim mrežama, povijest psihijatrijske bolesti i finansijski gubici.

Iako su rezultati brojnih studija ukazali na nepovoljne psihološke efekte karantene, važno je naglasiti da u nekim okolnostima karantena može rezultirati i povoljnim psihološkim efektima (Locke i sar., 2019). Naime, u literaturi o mentalnom zdravlju je dokumentovano da vlastita uvjerenja i stavovi igraju vrlo važnu ulogu u predviđanju emocionalnog funkcioniranja (Ayers i sar., 2010; Lyer i Munch, 2016). Rezultati nekih studija ( Aghababaei i sar., 2016; Ayers i sar., 2010; Halvorsen i sar., 2010; Kato i sar., 2016; Shallcross i sar., 2010) ističu da su negativni i pesimistički stavovi povezani s povećanje depresivne simptomatologije dok su pozitivni/optimistični stavovi pozitivno povezani sa životnim zadovoljstvom, srećom, i samopoštovanjem. Ukratko, pozitivni stavovi 
rezultiraju usvajanjem širokog spektra uspješnih mehanizama prilagodbe na štetne okolnosti te mogu imati zaštitne učinke protiv bolesti, invaliditeta i depresije (Kato i sar., 2016).

Upravo zato su Lu, Nie i Qian (2020) pristupili istraživanju utjecaja iskustva karantene i ličnih stavova prema COVID-19 na promjene mentalnog zdravlja. Ukupno 1849 ispitanika starosne dobi između $16 \mathrm{i}$ 65 godina iz 31 kineske provincije je bilo uključeno u ovu online studiju. Ovi autori su zaključili da je kod osoba koje su gajile pozitivan stav prema COVID-19 (smanjena percepcija ozbiljnosti bolesti, povjerenje $u$ pravovremenost $i$ istinitost izvještavanja te povjerenje $u$ sposobnost sistema da kontrolira širenje virusa) umanjena depresivna simptomatika dok je osjećaj sreće povećan. Nadalje se zaključuje da je samoodabrana karantena povezana $\mathrm{s}$ povećanim osjećajem sreće $\mathrm{i}$ sniženim depresivnim simptomima, što autori pripisuju vjerovanju da kućna karantena umanjuje rizik od infekcije. Naime, ovakva karantena se percipira kao dobrovoljan i racionalan izbor samozaštite što može dovesti do umanjenja straha od infekcije i na taj način povećanja osjećaja sreće. Suprotno navedenom, društvena karantena, kao preventivna mjera izrečena za cjelokupnu društvenu zajednicu, ostavlja ozbiljne i štetne psihološke posljedice. Navedeno se povezuje s osjećajem da je pandemija izmakla kontroli, da zdravstveni sistem države nije u stanju da se nosi s novonastalom situacijom, javlja se osjećaj prinude i panike. Karantena na nivou zajednice također utječe mnogo više na svakodevni život ljudi za razliku od samoodabrane kućne karantene.

\section{Utjecaj karantene na mentalno zdravlje zdravstvenih radnika}

Rezultati dosadašnjih istraživanja pokazuju da su, u vrijeme izbijanja epidemije ili pandemije određenih zaraznih bolesti, jedna od najvulnerabilnijih kategorija stanovništva upravo zdravstveni radnici koji su svakodnevno $\mathrm{u}$ direktnom ili indirektnom kontaktu $\mathrm{s}$ potencijalno zaraženim osobama (Amin, 2000; Kang, Ma, Chen, Yang, Wang i sar., 2020; Luo, Guo, Yu, Jiang i Wange, 2020).

Bai i saradnici (2004) su istraživali stresnu reakciju na uzorku od 338 zaposlenika u zdravstvenim ustanovama (218 zdravstvenih i 79 administrativnih radnika) $\mathrm{u}$ istočnom Taivanu koristeći posebno dizajnirani upitnik stresnih reakcija na SARS (SARS-related stress 
reactions questionnaire), koji se sastojao od DSM IV kriterija za akutni stresni poremećaj te povezanih emocionalnih promjena i promjena $\mathrm{u}$ ponašanju. Rezltati su pokazali da je 5\% zdravstvenih radnika patilo od akutnog stresnog poremećaja gdje je karantena predstavljala faktor koji najviše doprinosi ovom poremećaju, $20 \%$ ih se osjećalo stigmatizirano ili odbačeno od društvene zajednice zbog posla koji obavljaju, 15\% zdravstvenih radnika nakon posla nisu išli kući u vrijeme pandemije kako bi zaštitili porodicu od eventulne infekcije, dok je $9 \%$ zdravstvenih radnika izjavilo da im je teško da idu na posao ili da čak razmišljaju o prekidu radnog odnosa. Za razliku od administrativnog osoblja, zdravstveni radnici su češće izvještavali o pojavi nesanice, iscrpljenosti, teškoćama prilagođavanja na učestale promjene procedura kojima se nastojala uspostaviti kontrola nad širenjem zarazne bolesti.

Rezultati studije koju su Wu i saradnici (2009) proveli na 549 zdravstvenih radnika iz Beijinga (Kina) kako bi ispitali psihološke efekte epidemije SARS-a na zdravstvene radnike, pokazuju da je $10 \%$ učesnika doživjelo visok nivo posttraumatske stresne simptomatike nakon epidemije SARS-a. Vjerovatnoća pojavljivanja posttraumatske stresne simptomatike bila je veća dva do tri puta kod zdravstvenih radnika koji su bili u karanteni ili su radili na visoko rizičnim lokacijama ili su imali prijatelje/rođake koji su inficirani SARS-om u odnosu na one koji nisu bili izloženi ovim rizicima. Percepcija učesnika o rizicima vezanim za SARS se pokazala značajno povezanom s posttraumatskom stresnom simptomatikom, dok je altruistično prihvatanje rizika posla bilo negativno povezano s njenim intenzitetom. Autori zaključuju da efekti stresnih događaja, povezanih s izbijanjem zaraznih bolesti, na mentalno zdravlje pojedinca mogu biti moderirani percepcijom pojedinca o tim događajima. Tako altruizam može zaštititi neke zdravstvene radnike od nepovoljnih efekata.

Nadalje, uočeno je da su zdravstveni radnici koji su bili u karanteni imali izraženije simptome posttraumatskog stresa $\mathrm{u}$ poređenju $\mathrm{s}$ osobama iz opće populacije koje su također bile u karanteni. Zdravstveni radnici su češće izvještavali o stigmatizaciji, izbjegavajućim ponašanjima, značajnijim finansijskim gubicima te o intenzivnijim osjećanjima ljutnje, uznemirenosti, uplašenosti, frustriranosti, bespomoćnosti, usamljenosti, nervoze, izoliranosti, tuge 
i zabrinutosti. U poređenju s općom populacijom, zdravstveni radnici češće vjeruju da su zaraženi te samim tim osjećaju veći strah da će zaraziti druge (Reynolds i sar. 2008).

Posebno zanimljivo je pitanje kakav utjecaj na mentalno zdravlje radnika ima briga za osobe koje su u karanteni. Amin (2020) je na temelju istraživanja u Pakistanu, zaključio o prisustvu tzv. koronafobije na uzorku od 250 zdravstvenih radnika iz nekoliko bolnica, a koja je uzrokovala niz različitih psihopatoloških simptoma i narušila im mentalno zdravlje.

\section{Kritički osvrt na dosadašnja istraživanja o psihološkim efektima karantene}

Iako su rezultati o istraživanjima koje povezuju karantenu s negativnim psihološkim efektima dosad uglavnom konzistentni, većina njih obuhvaća mali uzorak; iz azijskih su područja i metodološkog dizajna koji ne omogućava utvrđivanje uzročno-posljedične veze, što značajno otežava generalizaciju ovih zaključaka. Općenito, značajno ograničenje ogleda se i u malobrojnosti ovakvih istraživanja. Imajući u vidu da pandemija COVID-19 još uvijek traje na globalnom nivou, potencijalna opasnost još uvijek nije prošla i neizvjesno je do kada će trajati te kakav će joj krajnji ishod biti. Teško je predvidjeti kakve će dugoročne posljedice ostaviti te kakav je utjecaj međusobnog odnosa karantene i drugih preventivnih mjere na mentalno zdravlje. Nedostaju istraživanja koja ispituju psihološke efekte roditelja čija su djeca u karanteni ili u bolničkim izolatorijima te obratno. Pregledom dostupnih radova aktualno nisu pronađena ni istraživanja koja se bave osobama u terminalnim fazama određenih bolesti, a koji su u bolničkoj karanteni, i njihovim članovima porodica koji nisu u mogućnosti da se na adekvatan način oproste s umirućim. Istraživanja su usmjerena na opću populaciju te je neophodno poticati njihovo provođenje na uzorcima iz kliničke populacije. U vezi s tim, korisno bi bilo ispitati utjecaj karantene na osobe s PTSP-om, pogotovo uzrokovanim ratnim traumama zatočeništva i boravka u logorima, pojavu/porast suicidalnog rizika, intenziviranje ili recidivi ranijih psihičkih poremećaja, kao i rizika od psihotičnih dekompenzacija. Također, važno je ispitati pojavu i/ili porast rizika od različitih vrsta nasilja u porodicama koje zajedno borave u kućnoj karanteni. 
Nadalje, s obzirom na manjak istraživanja o psihološkim efektima karantene u vrijeme pandemije COVID-19 uvrštena su i ranija istraživanja koja se odnose na period izbijanja epidemije drugih virusa. Međutim, poređenje njihovih rezultata otežavaju primjenjivani različiti dijagnostički kriteriji (DSM IV-DSM V).

\section{Zaključci}

S ciljem postizanja većeg javnog dobra, karantena, koja podrazumijeva značajnu preventivnu mjeru protiv širenja zaraznih bolesti, može stvoriti i iznimno teške psihološke, emocionalne te finansijske posljedice za pojedince. Kako bi bila efikasna, karantena zahtijeva, ne samo da se osobe u riziku izoliraju, nego, također, da poštuju jasno propisane mjere kontrole širenja zaraze unutar mjesta karantene. Na temelju dosadašnjih istraživanja i iskustva stečenog u praksi, zaključujemo da je razmatranje štetnih efekata karantene, uključujući psihološke efekte, do sada nedovoljno i neadekvatno analizirano i istraženo. Ovakav pregled rezultata istraživanja predstavlja izazove uvođenja karantenskih mjera po mentalno zdravlje pojedinaca, njihovih porodica i zajednice. Ova znanja su krucijalna ako želimo da moderna karantena predstavlja efikasnu strategiju suzbijanja širenja bolesti te da se paralelno usmjeri i na očuvanje mentalnog zdravlja onih kojima je ovakva mjera propisana. Uspješno korištenje karantene zahtijeva minimiziranje njenih potencijalnih negativnih psiholoških efekata. Kao jedno od efikasnih rješenja moglo bi se pokazati istovremeno uvođenje pružanja adekvatne psihosocijalne podrške osobama kojima je navedena mjera izrečena. Ključni faktor za pojedinca u karanteni jeste pravovremena i adekvatna informiranost $u$ cilju boljeg razumijevanja situacije u kojoj se nalaze (Wang i sar., 2020). S obzirom na razvoj situacije u pogledu širenja zarazne bolesti uzrokovane virosom COVID-19 u Bosni i Hercegovini, kao i susjednim državama, donosiocima odluka o karanteni kao preventivnoj mjeri se urgentno treba dostaviti na uvid pregled potencijalnih efekata ove mjere kako bi isti mogli donijeti što kvalitetnije i efikasnije odluke. Iz navedenih zaključaka proizilazi i preporuka da se psiholozi uključe u kreiranje preventivnih strategija zdravstvene politike za naše stanovništvo te zajednički s epidemiolozima i infektolozima ravnopravno i aktivno 
sudjeluju u održavanju i unaprijeđenju zdravlja te sprečavanja razvoja psihičkih bolesti kod ovih pojedinaca.

\section{Literatura}

1. Aghababaei N., Sohrabi F., Eskandari H., Borjali A., Farrokhi N. \& Chen, Z. J. (2016) Predicting subjective well-being by religious and scientific attitudes with hope, purpose in life, and death anxiety as mediators. Personality and Individual Differences, 90, 93-98.

2. Amin S. (2020) The psychology of corona virus fear: are healthcare professionals suffering from corona-phobia? International Journal of Healthcare Management, 13(3), 249-256.

3. Ayers B., Forshaw M. \& Hunter, M. S. (2010) The impact of attitudes towards the menopause on women's symptom experience: a systematic review. Maturitas, 65(1), 28-36.

4. Bai Y., Lin C-C., Lin C-Y., Chen J-Y., Chue C-M. \& Chou P. (2004) Survey of stress reactions among health care workers involved with the SARS outbreak. Psychiatric Services, 55(9): 1055-1057.

5. Barbera J., Macintyre A., DeAtley C., Gostin L., Inglesby T., O'Toole T., Tonat K., \& Layton M. (2001) Large-scale quarantine following biological terrorism in the United States: Scientific examination, logistic and legal limits, and possible consequences. Journal of the American Medical Association, 286(21), 2711-2717.

6. Cai X., Hu X., Otte E.I., Wang J., An Y., Li Z.\& Yuan B. (2020) Psychological Distress and Its Correlates Among COVID-19 Survivors During Early Convalescence Across Age Groups. The American journal of geriatric psychiatry, 10.

7. Casagrande M., Favieri F., Tambelli R. \& Forte G. (2020) The enemy who sealed the world: Effects quarantine due to the COVID-19 on sleep quality, anxiety, and psychological distress in the Italian population. Sleep Medicine, 75: 12-20.

8. Cava M., Fay K.E., Beanlands H.J., McCay M. \& Wignall R. (2005) Risk Perception and Compliance With Quarantine During the SARS Outbreak. Journal of nursing scholarship, 37(4): 343-7.

9. Cava M., Fay K.E., Beanland H.J., McCay E.A. \& Wignall R. (2005) The Experience of Quarantine for Individuals Affected by SARS in Toronto. Health Nursing, 22(5):398-406.

10. Centers for Disease Control and Prevention Quarantine and isolation. (2017) https://www.cdc.gov/quarantine/index.html (accessed Jan 30, 2020). 
11. Desclaux A., Badji D., Ndione A.G. \& Sow K. (2017) Accepted monitoring or endured quarantine? Ebola contacts' perceptions in Senegal. Social Science \& Medicine 178: 38-45.

12. DiGiovanni C., Conley J., Chiu D. \& Zaborski J. (2004) Factors Influencing Compliance with Quarantine in Toronto During the 2003 SARS Outbreak. Biosecurity and Bioterrorism: Biodefense Strategy, Practice and Science, 2(4): 265-72.

13. Fawaz M. \& Samaha A. (2020) COVID-19 quarantine: Post-traumatic stress symptomatology among Lebanese citizens. International Journal of Social Psychiatry, 1-9.

14. Halvorsen M., Wang C. E., Eisemann M. \& Waterloo, K. (2010) Dysfunctional attitudes and early maladaptive schemas as predictors of depression: a 9-year follow-up study. Cognitive Therapy and Research, 34(4), 368-379.

15. Hawryluck L., Gold W.L., Robinson S., Pogorski S., Galea S. \& Styra R. (2004) SARS control and psychological effects of quarantine, Toronto, Canada. Emerging infectious diseases, 10(7): 1206-1212.

16. Jeong H., Yim W.Y., Song Y-J., Ki M., Min J-A., Cho J. \& Chae J-H. (2016) Mental health status of people isolated due to Middle East Respiratory Syndrome. Epidemiology and Health, 38.

17. Kang L., Ma S., Chen M., Yang J., Wang Y., Li R., L., Yaho \& sar. (2020) Impact on mental health and perceptions of psychological care among medical and nursing staff in Wuhan durin the 2019 novel coronavirus disease outbreak: A cross-sectional study. Brain, Behavavior and Immununity 87, 11-17.

18. Kato K., Zweig R., Schechter C. B., Barzilai N. \& Atzmon, G. (2016) Positive attitude toward life, emotional expression, self-rated health, and depressive symptoms among centenarians and near-centenarians. Aging \& Mental Health, 20(9), 930-939.

19. Lee S., Chan L.Y., Chau A.M., Kwok K.P. \& Kleinman A. (2005) The experience of SARS-related stigma at Amoy Gardens. Social Science and Medicine, 61(9): 2038-46.

20. Liu X., Kakade M., Fuller C.J., Fan B., Fang Y., Kong J., Guan Z. \& Wu P. (2012) Depression after exposure to stressful events: lessons learned from the severe acute respiratory syndrome epidemic. Comprehensive Psychiatry, 53: 15-23.

21. Locke B., Low M. \& Forsgren E. (2019) An integrated management strategy to prevent outbreaks and eliminate infection pressure of American foulbrood disease in a commercial beekeeping operation. Preventive Veterinary Medicine, 167, 48-52. 
22. Lu H., Nie P. \& Qian L. (2020) Do Quarantine Experiences and Attitudes Towards COVID-19 Affect the Distribution of Psychological Outcomes in China? A Quantile Regression Analysis, GLO Discussion Paper, No. 512, Global Labor Organization (GLO), Essen.

23. Luo M., Guo L., Yu M., Jiang D. \& Wange H. (2020) The psychological and mental impact of coronavirus disease 2019 (COVID-19) on medical staff and general public - A systematic review and meta-analysis. Psychiatry Research.

24. Madani A., Boutebal S.E. \& Bryant C.R. (2020) The Psychological Impact of Confinement Linked to the Coronavirus Epidemic COVID-19 in Algeria. International Journal of Environmental Research and Public Health, 17(10), 3604.

25. Mandavilli A. (2003) SARS epidemic unmasks age-old quarantine conundrum. Nature Medicine, 9(5): 487.

26. Mihashi M., Otsubo Y., Yinjuan X., Nagatomi K., Hoshiko M. \& Ishitake T. (2009) Predictive factors of psychological disorder development during recovery following SARS outbreak. Health Psychology, 28(1), 91-100.

27. Pan P.J., Chang S-H. \& Yu Y-Y. (2006) A Support Group for HomeQuarantined College Students Exposed to SARS: Learning from Practice. The Journal for Specialists in Group Work, 30(4), 363-374.

28. Penga M., Mob B., Liub Y., Xub M., Songa X., Liua L., Fangb Y., Guoc T., Yec J., Yud Z., Dengd Q. \& Zhange X. (2020) Prevalence, risk factors and clinical correlates of depression in quarantined population during the COVID-19 outbreak. Journal of Affective Disorders, 275, 119-124.

29. Reynolds D.L., Garay S.L., Deamond S.L., Moran M.K., Gold W. \& Styra R. (2008) Understanding, compliance and psychological impact of the SARS quarantine experience. Epidemiology and Infection, 136(7), 997-1007.

30. Shallcross A. J., Troy A. S., Boland M. i Mauss, I. B. (2010) Let it be: accepting negative emotional experiences predicts decreased negative affect and depressive symptoms. Behaviour Research and Therapy, 48(9), 921-929.

31. Sheng, N., Liu, F, Zhou, J \& Liao, R. (2020) Psychological status and sleep quality of nursing interns during the outbreak of COVID-19.

32. Sprang G. \& Silman M. (2013) Posttraumatic stress disorder in parents and youth after health-related disasters. Disaster Medicine and Public Health Preparedness, 7(1):105-110. 
33. Taylor M.R., Agho K.E., Stevens G.J. \& Raphael B. (2008) Factors influencing psychological distress during a disease epidemic: data from Australia's first outbreak of equine influenza. BMC Public Health, 8: 347.

34. Twu S.J., Chen T.J., Chen S.J., Olsen S.J., Lee L.T., Fisk T., Hsu K.H., Chang S.C., Chen K.T., Chiang I.H., Wu Y.C., Wu J.S. \& Dowell S.F. (2003) Control Measures for Severe Acute Respiratory Syndrome (SARS) in Taiwan. Emerging infectious diseases, 9(6): 718-720.

35. Wang C., Pan R., Wan X., Tan Y., Xu L., Ho C.S. \& Hol R.C. (2020) Immediate Psychological Responses and Associated Factors during the Initial Stage of the 2019 Coronavirus Disease (COVID-19) Epidemic among the General Population in China. International Journal of Environmental Research and Public Health, 17(5).

36. Wu P., Fang Y., Guan Z., Fan B., Kong J., Yao Z., Liu X., Fuller C. J., Susser E.,Lu J. i Hoven C. W. (2009) The psychological impact of the SARS epidemic on hospital employees in China: exposure, risk perception, and altruistic acceptance of risk. Canadian Journal of Psychiatry 2009; 54: 302-311.

37. Yoon M.K., Kim S.Y., Ko H.S. \& Lee M.S. (2016) System effectiveness of detection, brief intervention and refer to treatment for the people with post-traumatic emotional distress by MERS: a case report of community-based proactive intervention in South Korea. International Journal of Mental Health Systems, 10(51). 
Vildana Aziraj-Smajic

Cantonal Hospital "Dr. Irfan Ljubijankić",

Department of Neuropsychiatry, Bihać,

Email:v.aziraj@gmail.com

Mirela Mujagic

Cantonal Court in Bihać

E-mail:poprzenovicm@gmail.com

\section{PSYCHOLOGICAL EFFECTS OF QUARANTINE DURING THE COVID-19 PANDEMIC}

\section{Abstract}

Many countries, including Bosnia and Herzegovina, have put entire cities in quarantine and introduced police hours believing that those are the most successful measures in terminating the outbreak of COVID-19. Even though quarantine can be very effective in terminating disease outbreak, at the same time it could be a very unpleasant experience for those who undergo it. Physical distancing from loved ones, lack of belief in the bealth system, the loss of freedom of

movement, limitation in everyday activities and habits, could result with high prevalence of anxiety, depression, symptoms of posttraumatic stress disorder as well as other psychopathological symptomatology. With the aim of avoiding discomfort resulting from the quarantine, some individuals decide to conceal symptoms of COVID-19 which can have adverse effects on public health. Having this in mind, it is understandable that the research focus has been on examining the psychological effects of quarantine. Some authors believe that the COVID-19 pandemic will result with a pandemic of psychological disorders. The aim of this review is to evaluate published, previous and current literature and research results on effects of quarantine on psychological health and to apply and integrate those into the current health care system in Bosnia and Herzegovina. It is not our intention to present quarantine as an undesirable prevention method but to increase awareness about the importance of mental health hygiene for those who undergo it.

Key words: quarantine, COVID-19, psychological effects 


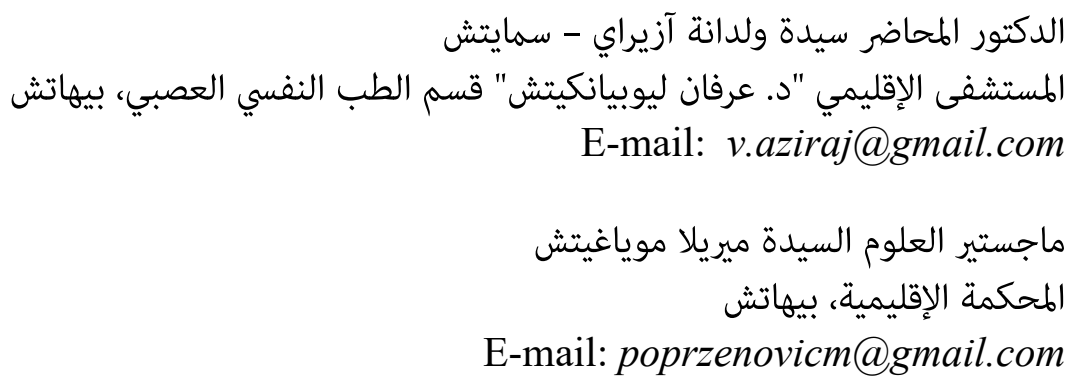

الآثار النفسية للحجر الصحي أثناء انتشار وباء كوفيد -19

\section{الخلاصة}

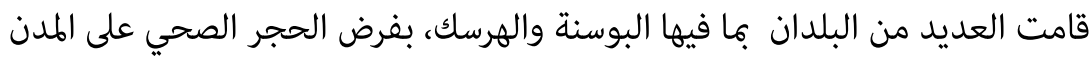

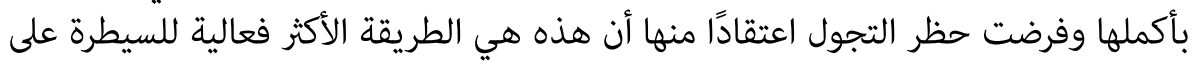

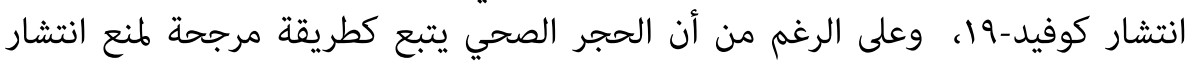

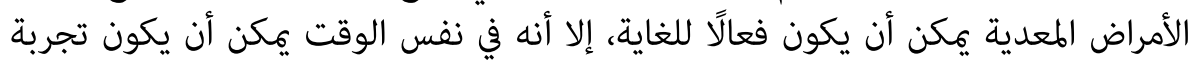

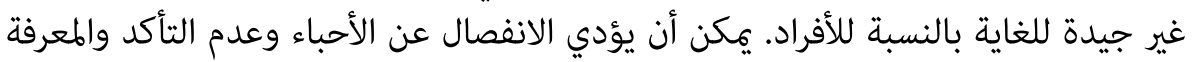

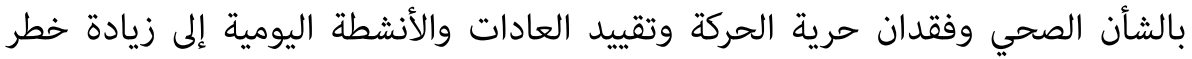

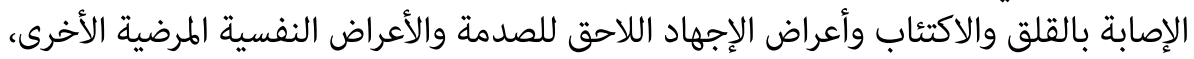

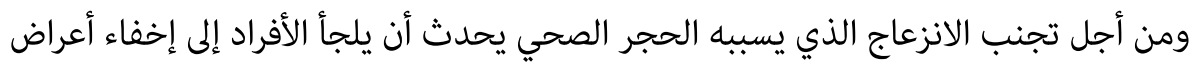

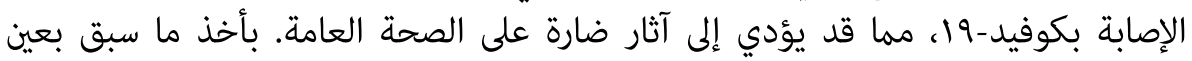

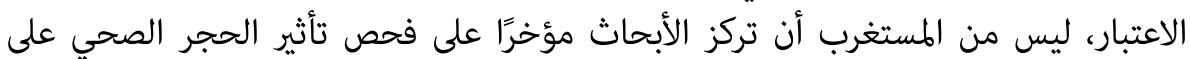

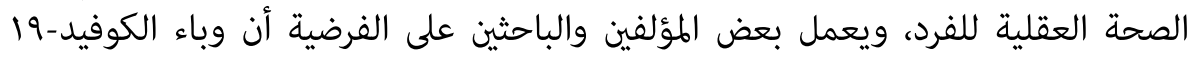

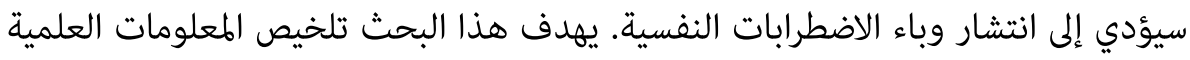

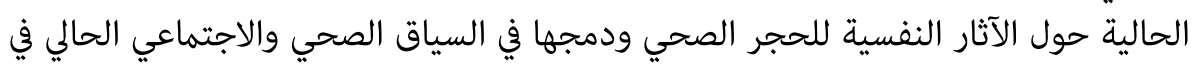

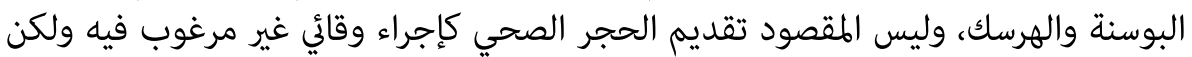

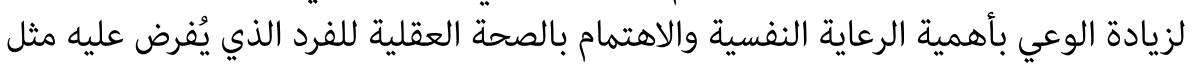
هذا الإجراء. 